\title{
Ortaokul öğrencilerinin proje hazırlama ve eğitim alma isteklerine yönelik görüş- lerinin değişkenlere göre incelenmesi
}

\author{
Investigation of secondary school students' opinions on project preparation and requests re- \\ ceive education according to variables
}

\author{
Hatice Karaer ${ }^{1}$ ve Emre Soytürk ${ }^{2}$ \\ ${ }^{1}$ Dr. Öğrt. Üyesi, Ondokuz Mayls Ün., Samsun/Türkiye, e mail: hkaraer@omu.edu.tr, ORCID: https://orcid.org/0000-0001-7745-9387 \\ ${ }^{2} Y$ Öğrencisi, Ondokuz Mayls Ün., Samsun/Türkiye, e mail: emresoyturk1987@gmail.com, ORCID: https://orcid.org/0000-0003-4392-6121
}

\begin{tabular}{|c|c|}
\hline Makale Bilgisi & $\ddot{O}_{z}$ \\
\hline $\begin{array}{l}\text { Araştırma Makalesi } \\
\text { Gönderilme: } 3 \text { Mayıs } 2021 \\
\text { Düzeltme: } 19 \text { Ăgustos } 2021 \\
\text { Kabul: } 22 \text { Eylül } 2021 \\
\text { Anahtar kelimeler: } \\
\text { Proje, } \\
\text { Proje hazırlama, } \\
\text { Proje eğitimi, } \\
\text { Proje tabanll öğrenme, }\end{array}$ & 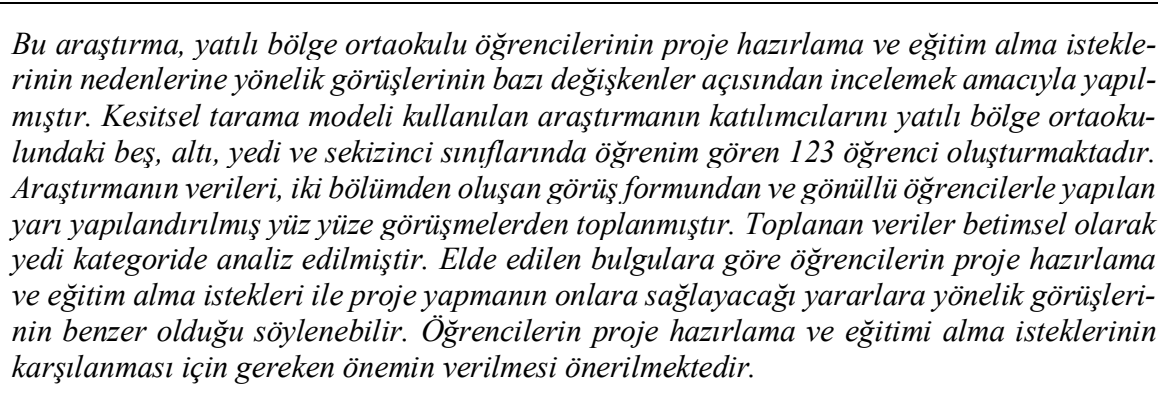 \\
\hline
\end{tabular}

Ortaokul ögrencileri

\begin{tabular}{|c|c|}
\hline Article Info & Abstract \\
\hline Research Article & $\begin{array}{l}\text { This research was carried out to examine the opinions of regional boarding secondary } \\
\text { school students regarding the reason for their desire to prepare projects and receive educa- }\end{array}$ \\
\hline Received:3 May 2021 & tion according to some variables. Using the cross-sectional survey model, the participants \\
\hline Revised: 19 August 2021 & of the research consist of 123 students from the fifth, sixth, seventh and eighth grade students \\
\hline Accepted: 22 September 2021 & $\begin{array}{l}\text { in the in the regional boarding secondary. The data were collected from a two-part interview } \\
\text { form and semi-structured face-to-face interviews with volunteer students. Collected data }\end{array}$ \\
\hline Keywords: & were analyzed descriptively in seven categories. According to the findings, it can be said \\
\hline Project, & that students' desire to prepare projects and receive an education and their views on the \\
\hline $\begin{array}{l}\text { Project preparation, } \\
\text { Project education, }\end{array}$ & $\begin{array}{l}\text { benefits of doing projects are similar. It is recommended to give the necessary importance } \\
\text { to meet the students' requests for project preparation and receive an education. }\end{array}$ \\
\hline
\end{tabular}

Project-based learning,

Secondary school students

\section{Giriş}

Geçmişten günümüze uzanan süreçte insanoğlu karşı karşıya kaldığı bir problemi çözebilmek için var gücüyle çalışır ve tamamını olmasa da bir kısmını çözer, çözemezse yeni çözüm yolları arar. Böylece mevcut bilgilerin üstüne yeni bilgiler ekleyerek kendisini bir geliştirme süreci içerisinde bulur. Problemlerin çözümü her zaman bilinçli ve düzenli gerçekleşmeyebilir. Bilinçli veya rastgele olsa da insanoğlunun bilgiye ulaşma macerası genelde bir etkileşim sonucu meydana gelmektedir. Bilgiye ulaşmanın veya problemlere çözüm üretmenin yolu merak, araştırma, inceleme, bilişsel düşünme vb. süreçlerin olması durumunda gerçekleşebilmektedir (Erdem, 2002).

\footnotetext{
* Bu araştırma T.C. Ondokuz Mayıs Üniversitesi Sosyal ve Beşeri Bilimler Etik Kurulunun 28.03.2019 tarih ve 3/2019-52 kararı ile etik açından uygun bulunmuştur. Tüm sorumluluk yazarına aittir.
}

Kaynak göster: Karaer, H. \& Soytürk, E. (2021). Ortaokul öğrencilerinin proje hazırlama ve eğitim alma isteklerine yönelik görüşlerinin değişkenlere göre incelenmesi. International Journal of Social Sciences and Education Research, 7 (4), 321-336. DOI: https://doi.org/10.24289/ijsser.932117 
Gelişmiş ülkeler, eğitim sistemlerini bilgiye ulaşma becerisine sahip donanımlı bireyler yetiştirmek üzerine kurmuşlardır. Özellikle matematik ve fen alanlarında köklü değişikliklerle eğitim sistemlerini yapılandırarak öğrenciyi merkeze alan öğrenme yaklaşımlarına göre öğretim programlarını düzenlemişlerdir. Bireysel veya küçük gruplar halinde yaşamla uyumlu doğal ortam ve şartlarda bir problemi çözebilmeyi amaçlayan Proje Tabanlı Öğrenme (PTÖ) öğrenci merkezli bir yaklaşımdır. Bu yaklaşım öğrencilere problem çözme becerisi kazandırırken onların sözlü, yazılı iletişim becerilerini geliştirme, kolay öğrenmelerini sağlama, kendilerine olan güvenlerini artırma ve araştırma alanıyla ilgili meraklarını gidermeyi sağlamaktadır. Ayrıca öğrencilerin ilgilerini arttırma, kendi başlarına bağımsız düşünme, çalışma ve başarma cesaretini kazandırma, eleştirel düşünme yeteneğini geliştirme gibi etkileri bulunmaktadır (Aslanides, Kalfa, Athanasiadou, Gianelos \& Karapatsias, 2016; Bayraktar, 2015; Korkmaz ve Kaptan, 2001).

PTÖ, öğrencilere bilim insanlarının çalışma şartlarındaki zorluğu, onların gösterdikleri gayretleri, bilimsel çalışma süreçlerini anlama, problem çözmeyi öğrenme ve geliştirme, araştırma yapmaya yönlendirme, boş zamanlarını yararlı ve anlamlı etkinliklerle değerlendirerek bilimsel çalışma alışkanlığı kazandırmaktadır (Akçöltekin ve Akçöltekin, 2017; Schnider, Kracjcik, Marx \& Soloway, 2002). PTÖ öğrencilerin öz-yeterlilik inançlarını olumlu yönde artırma, onları bilime teşvik etme (Karaer, Karademir ve Tezel, 2020), öğrenme sürecinde görev ve sorumluluk alarak bir ürün ortaya koymalarını sağlamaktadır (Özel, 2013).

PTÖ yaklaşımını eğitim sisteminin içine önceki yıllarda dâhil eden ülkeler olsa da Türkiye'de 2002'den sonra hız kazanmış ve özellikle TÜBİTAK'ın önem vermesinden sonra yaygınlaşmaya başlamıştır (Karaer, Karaer ve Şahin, 2009; Karaer, Karaer, Şahin ve Parmaksız, 2010). Her ne kadar okullarda pek çok öğrencinin proje yapmadığı ya da yeteri kadar proje çalışması içinde bulunmadığı bilinse de TÜBİTAK ve yerel yönetimlerin öğretmen ve öğrencileri proje çalışmaya teşvik ettiği, bu konuda eğitimler verdiği ve yarışmalar düzenlediği bilinmektedir (Karaer ve Karaer, 2012a, b; Karaer, Karaer, Parmaksız ve Akaydın, 2010).

\section{Literatür}

Alan yazında PTÖ yaklaşımının hemen her disipline uygulanabildiğini gösteren çok sayıda çalışma bulunmaktadır (Akgül, 2011; Akın, 2016; Erdem, 2008; İmer, 2008). PTÖ’ nün eğlenceli olduğu, grup çalışmalarını desteklediği, öğrencilerin zorluklarla mücadele ettiği, gerçeği aramaya ve eleştirel düşünmeye teşvik ettiği, iletişim becerilerini geliştirdiği, öğrencilerin akademik başarı ve tutumlarını artırdığı gibi olumlu katkısının olduğuna yönelik pek çok çalışma mevcuttur. Bu çalışmalarda PTÖ yaklaşımının öğrencilerin akademik başarısına ve tutumlarına (Atik, 2009; Acar, 2011; Karaçall1, 2011; Kızkapan, 2015; Köse, 2010; Kummin \& Rahman, 2010, Quek, Wong, Diyaraharan, Liu, Peer \& Williams, 2007) etkisini inceleyen çalışmaların çoğunlukta olduğu belirlenmiştir. Yavuz ve Yavuz (2017), 2002-2014 yılları arasında fen eğitiminde PTÖ ile ilgili yüksek lisans ve doktora düzeyindeki tezlerin içeriğinin daha çok öğrenci başarısı ve tutuma etkilerinin araştırıldığını açıklamışlardır. Filiz ve Kocakülah (2020), 2002-2019 yılları arasındaki PTÖ ile ilgili makale ve tezleri inceledikleri çalışmada PTÖ fen eğitiminde akademik başarı ve tutumu artırdığını belirtmişlerdir. Bu çalışmaların yanında PTÖ’ nün, öğrencilerin mantıksal düşünmeye (Çıbık, 2006) ürün oluşturma isteğine (Demirhan, 2002), kalıcılığına (Karaçallı, 2011), akademik özyeterliklerine ve motivasyonlarına (Aydın, Atalay ve Göksu, 2017), bilgi verme (Bayraktar, 2015; Korkmaz ve Kaptan, 2001), meta analiz (Yavuz ve Yavuz, 2017) ile ilgili çalışmaların yanında öğrenci, öğretmen ve veli görüşlerini içeren çalışmalarda mevcuttur (Ay, 2013; Civelekoğlu ve Öztürk, 2010; Çetin ve Şengezer, 2013; İdin ve Özdemir Şimşek, 2016; Karasu, 2012; Kılıç ve Özel, 2015; Kılıç ve Özmen, 2021; Koparan, Karpuz ve Güven, 2014; Nacaroğlu, Arslan ve Bektaş, 2019; Özel, 2013). Bu çalışmaların büyük çoğunluğunda PTÖ’ nün uygulamasına yönelik görüşler yer almaktadır.

Ortaöğretim "Proje Uygulamaları” ders kitabında öğrencileri proje uygulamalarına istekli olmaya teşvik edilmesi gerektiği belirtilmesinin yanında bilimsel amaçlı ve büyük çapta bilgi edinme süreci olarak algılanmaması gerektiği de vurgulanmaktadır (Olgun, Yavuz ve Yokuş, 2019). Proje hazırlama uzun soluklu bir süreci kapsadığı düşünüldüğünde PTÖ yaklaşımı uygulanmadan önce öğrencilerin proje hakkında neler düşündüğü, olumlu olumsuz görüşlerinin olup olmadığı, proje hazırlamaya ve eğitim almaya istekli olup olmadıkları, proje hakkında çekincelerinin bulunup bulunmadığ söylenebilir. Ayrıca PTÖ’ nün uygulaması yapılmadan önce öğrenci görüşlerinin belirlenmesi uygulama yapılırken öğretim sürecinin daha verimli geçmesine ve daha yaratıcı projelerin ortaya çıkmasına yardımcı olacağı düşünülmektedir.

Alan yazında PTÖ ile ilgili öğrenci görüşleri içeren çalışmaların daha çok PTÖ’ nün uygulanmasına yönelik olması, uygulama yapılmadan önce öğrenci görüşleri içeren çalışmaların çok az olması ve uygulama öncesinde öğrencilerinin proje hazırlama ve eğitim alma istekli olup olmadıklarına yönelik görüşlerinin belirlenmesinin 
önemli olduğu düşünülmektedir. Bu düşünceden hareketle bu araştırma, YBO öğrencilerinin proje hazırlama ve eğitim alma isteklerinin nedenlerine yönelik görüş ve düşüncelerinin neler olduğunu ve değişkenler (cinsiyet, sinıf düzeyi, fen bilimleri dersini sevme, gitmek istedikleri lise türü ve gelecekte çalı̧̧ak istedikleri meslek grubu) açısından nasıl değiş̧tiğini incelemek amacıyla yapılmıştır. Bu amaçla YBO öğrencilerinin proje hazırlama ve eğitim alma isteklerinin nedenlerine yönelik görüş ve düşüncelerinin değişkenlere göre nasıl değişmektedir? Sorusu araştırmanın ana problemi olarak alınmıştır. Bu ana problem kapsamında dört alt problem belirlenmiş olup aşağıda verilmiş̧ir:

1- Öğrencilerin proje hazırlama ve eğitim alma isteklerinin frekans ve yüzde değerleri nasıl değişmektedir?

2- Öğrencilerin proje hazırlama isteklerinin nedenlerine yönelik görüş ve düşüncelerinin değişkenlere göre frekansları nasıl değişmektedir?

3- Öğrencilerin proje eğitimi alma isteklerinin nedenlerine yönelik görüş ve düşüncelerinin değiş̧kenlere göre frekansları nasıl değişmektedir?

4- Öğrencilerin proje hazırlama ve eğitim almanın onlara sağlayacağı yararlara yönelik görüş ve düşüncelerinin değişkenlere göre frekansları nasıl değişmektedir?

\section{Yöntem}

Bu bölümde araş九ırmanın modeli, katılımcıları, veri toplama araçları, verilerin analizi, geçerlilik ve güvenilirlik yer almaktadır. Bu araştırma Ondokuz Mayıs Üniversitesi Sosyal ve Beşeri Araştırmaları Etik Kurulunun 28.03. 2019 tarih ve 3/2019-52 sayılı kararı ile etik açıdan uygun bulunmuştur.

\subsection{Araștırmanın modeli}

Araştırmada geçmişte veya halen mevcut olan bir durumu olduğu haliyle tek seferde betimlemeyi amaçlayan kesitsel tarama modeli (Karasar, 2013) kullanılmıştır. Öğrencilerinin proje hazırlama ve eğitim alma isteklerinin nedenlerine yönelik görüşlerinin değişkenlere (cinsiyet, slnıf, fen bilimleri dersini sevme, gitmek istedikleri lise türü ve çalışmak istedikleri meslek grubu) göre mevcut durum analiz edildiğinden bu model uygun görülmüştür.

\subsection{Araş̧ırmanin katılımcıları}

Araştırmanın katılımcılarını 2018-2019 eğitim öğretim yılının Güz yarıyılında Karadeniz Bölgesinde bulunan YBO beş, altı, yedi ve sekizinci sınıflarda öğrenim gören 123 gönüllü öğrenci oluşturmaktadır. Öğrencilerin kişisel bilgilerinin frekans ve yüzde değerleri Tablo 1 'de verilmiştir.

Tablo 1. YBO öğrencilerinin demografik bilgilerin frekans ve yüzde değerleri

\begin{tabular}{|c|c|c|c|}
\hline Değişken & Düzey & $\mathrm{f}$ & $\%$ \\
\hline \multirow[t]{2}{*}{ Cinsiyet } & Kadın & 56 & 45,5 \\
\hline & Erkek & 67 & 54,5 \\
\hline \multirow[t]{4}{*}{ Sinif } & 5. & 23 & 18,7 \\
\hline & 6. & 28 & 22,8 \\
\hline & 7. & 41 & 33,3 \\
\hline & 8. & 31 & 25,2 \\
\hline \multirow[t]{3}{*}{ Fen bilimleri dersini sevme } & Evet & 81 & 65,9 \\
\hline & Hayır & 6 & 4,9 \\
\hline & K1smen & 36 & 29,3 \\
\hline \multirow[t]{4}{*}{ Gitmek istediği lise türü } & Fen & 53 & 43,1 \\
\hline & Anadolu & 34 & 27,6 \\
\hline & Meslek & 17 & 13,8 \\
\hline & Diğer & 19 & 15,4 \\
\hline \multirow[t]{5}{*}{ Çalışmak istediği meslek grubu } & Sağlık & 33 & 26,8 \\
\hline & Güvenlik & 38 & 30,9 \\
\hline & Hukuk & 8 & 6,5 \\
\hline & Eğitim & 34 & 27,6 \\
\hline & Diğger & 10 & 8,1 \\
\hline
\end{tabular}

Tablo 1'de YBO öğrencilerinin \%45,5'u kadın, \%54,5'u erkektir. Araştırmaya en fazla katılım yedinci sınıf $(\% 33,3)$ öğrencilerinden olurken en az $(\% 18,7)$ beşinci sınıf öğrencilerinden olduğu görülmektedir. Öğrencilerden 
sadece $\% 4,9$ 'u fen bilimleri dersini sevmediği, $\% 43,1$ 'i fen lisesine $\% 15,4$ 'ü imam hatip vb. liselere gitmek istediği, \%30,9'u güvenlik ve \%6,5'u hukuk alanlarında çalışmak istediği görülmektedir.

\subsection{Veri toplama aract}

Veriler, iki bölümden oluşan görüş formundan ve yarı yapılandırılmış yüz yüze görüşmelerden toplanmıştır. Görüş formunun birinci bölümünde öğrencilerin kişisel bilgilerine yönelik beş soru bulunmaktadır (Tablo 1). İkinci bölümde öğrencilerin proje hazırlama ve eğitim alma istekleriyle ilgili beş soru yer almaktadır. Soruların ikisi kapalı üçü açık uçlu olup aşağıda verilmiştir:

1. Proje hazırlamak ister misiniz? (Evet/Hayır)

2. Neden proje hazırlamak istiyorsunuz?

3. Proje eğitimi verilmiş olsa katılmak ister misiniz? (Evet/Hayır)

4. Neden proje eğitimine katılmak istiyorsunuz?

5. Proje hazırlamak ve eğitimini almak size ne gibi yararlar saylayabilir?

Görüş formu çoğaltılmadan önce uzman görüşleri alınmış onların görüş ve önerileri doğrultusunda gerekli düzeltmeler yapıldıktan sonra forma son şekli verilmiştir. Araştırmanın katılımcılarına görüş formu ile ilgili bilgiler verildikten sonra görüşlerini rahatça yazabilecekleri ve birbirini etkilemeyecekleri bir sinıfta formu doldurmaları sağlanmıştır. Ayrıca her sınıftan gönüllü öğrencilerle sadece araştırmacının ve adayın olduğu sessiz bir ortamda görüş formundaki sorulara benzer sorularla yarı yapılandırılmış görüşmeler gerçekleştirilmiştir. Tüm görüşmeler ses kayıt cihazı ile kaydedilmiş, araştırmacı tarafindan kâğıda aktarılmış ve daha sonra öğrencilere okutularak teyit ettirilmiştir. Toplanan tüm verilerde öğrencilerin kimliği saklı tutulmuş ve Ö1, Ö2, ..Ö122, Ö123 şeklinde kodlar verilmiştir. Yarı yapılandırılmış görüşme tekniğinde araştırmacı önceden soracağı soruları içeren bir protokolü hazırlamak zorunda değildir. Katılımcıyla yaptığı görüşmenin akışına göre hazırladığı soruların yanında başka soruları sorabilir veya araştırmacı katılımcılardan aldığı yanıtları yeterli görebilir ya da daha ayrıntılı şekilde isteyebilir hatta katılımcı bir soruyu daha önce başka soruda yanıtlamışsa araştırmacı tekrar aynı soruyu sormayabilir (Ekiz, 2003).

\subsection{Verilerin analizi}

Görüş formundaki öğrencilerin demografik bilgileri ve kapalı uçlu iki sorunun yanıtları frekans ve yüzde değerleri şeklinde verilirken açık uçlu ve yarı yapılandırılmış görüşmelerdeki soruların yanıtlarından oluşturulan kategorilerdeki kodların frekansları değişkenlere göre tablolar halinde verilmiştir. Öğrencilerin görüşlerinden oluşturulan kategoriler sırasıyla "Proje hazırlamayı isteme", "Proje hazırlamayı istememe" "Proje eğitimi almayı isteme", "Proje eğitimi almayı istememe, "Her ikisini birden yapmayı isteme", "Her ikisini birden yapmayı istememe" ve "Proje yapmanın sağlayacağı yararlar" şeklinde değişmektedir.

Görüş formundaki açık uçlu soruların yanıtlarının analizinde betimsel analiz tekniği kullanılmıştır. Bu teknikte araştırma sorularının ortaya koyduğu tema ve kategorilere göre düzenlenebileceği gibi görüşme ve gözlem süreçlerinde kullanılan sorular veya boyutlara göre de verilebilir. Bu amaçla elde edilen veriler, sistematik ve belirgin bir biçimde betimlendikten sonra açıklanarak yorumlanır, neden-sonuç ilişkileri kurularak belli başlı sonuçlara ulaşılır. Araştırmacının ortaya koyduğu tema ve kategorilerin ilişkilendirilmesi, anlamlandırılması ve ileriye yönelik tahminlerde bulunulması araştırmacının yapacağı boyutlar arasında yer alabilir. Ayrıca araştırmacı katılımcıların görüş ve düşüncelerini etkili bir şekilde yansıtmak için doğrudan alıntılara yer verilebilir (Yıldırım ve Şimşek, 2006).

\subsection{Geçerlilik ve güvenilirlik}

Araştırmanın katılımcılarını oluşturan YBO öğrencilerinin kişisel bilgileri, veri toplama araçları, toplanan verilerin neden toplandığı ve nasıl analiz edildiğine yönelik gerekli tüm bilgiler yöntem bölümünde detaylandırılarak açıklandığı için geçerliliği sağlandığı düşünülmektedir. Öğrencilerin proje hazırlama ve eğitim alma isteklerinin nedenlerine yönelik görüşlerinden oluşturulan kategori ve kodlar, araştırma verilerinden elde edilen bulgularla araştırma sonuçlarının uygun olup olmadığını teyit ettirmek için uzman görüşünün alınması ve araştırmacıların araştırmadaki rolünü net olarak göstermesi çalışmanın güvenilirliğinin sağlandığı düşünülmektedir.

\section{Bulgular}

Bu bölümde elde edilen veriler araştırmanın amacı ve alt problemleri dikkate alınarak tablolar halinde verilmiştir. 


\subsection{Birinci alt probleme iliş̧kin bulgular}

YBO öğrencilerin proje hazırlama ve eğitim alma isteklerinin frekans ve yüzde değerleri Tablo 2'de verilmiş̧tir.

Tablo 2. YBO öğrencilerin proje hazırlama ve eğitim alma istekleriyle ilgili görüşlerinin frekans ve yüzde değerleri

\begin{tabular}{|c|c|c|c|c|c|c|}
\hline \multirow[t]{2}{*}{$\overline{\text { İsteği }}$} & \multicolumn{2}{|c|}{ Evet } & \multicolumn{2}{|c|}{ Hayır } & \multicolumn{2}{|c|}{ Yanitsiz } \\
\hline & $\mathrm{f}$ & $\%$ & $\mathrm{f}$ & $\%$ & $\mathrm{f}$ & $\%$ \\
\hline Proje hazırlama & 91 & 74,0 & 28 & 22,7 & 4 & 3,3 \\
\hline Proje eğitimi alma & 96 & 78,0 & 27 & 22,0 & & \\
\hline Her ikisi birlikte yapma & 85 & 69,1 & 38 & 30,9 & & \\
\hline
\end{tabular}

Tablo 2 incelendiğinde öğrencilerin \%74,0’ü proje hazırlamak istediğini belirtirken \%3,3’ü soruyu yanıtsız bırakmıştır. \%78,0'i proje eğitimi almak isterken \%22,7'si istememektedir. Her ikisini birden (proje hazırlama ve eğitimini alma) yapmak isteyen öğrencilerin $\% 69,1$ olduğu belirlenmiştir.

\section{2. İkinci alt probleme ilişkin bulgular}

YBO öğrencilerin proje hazırlama isteklerinin nedenleriyle ilgili görüş ve düşüncelerinden oluşturulan kodların değişkenlere göre frekansları Tablo 3 ve 4'de verilmiştir.

Tablo 3. YBO öğrencilerin proje hazırlamayı isteme nedenlerine yönelik görüşlerinden oluşturulan kodların değişkenlere göre frekansları

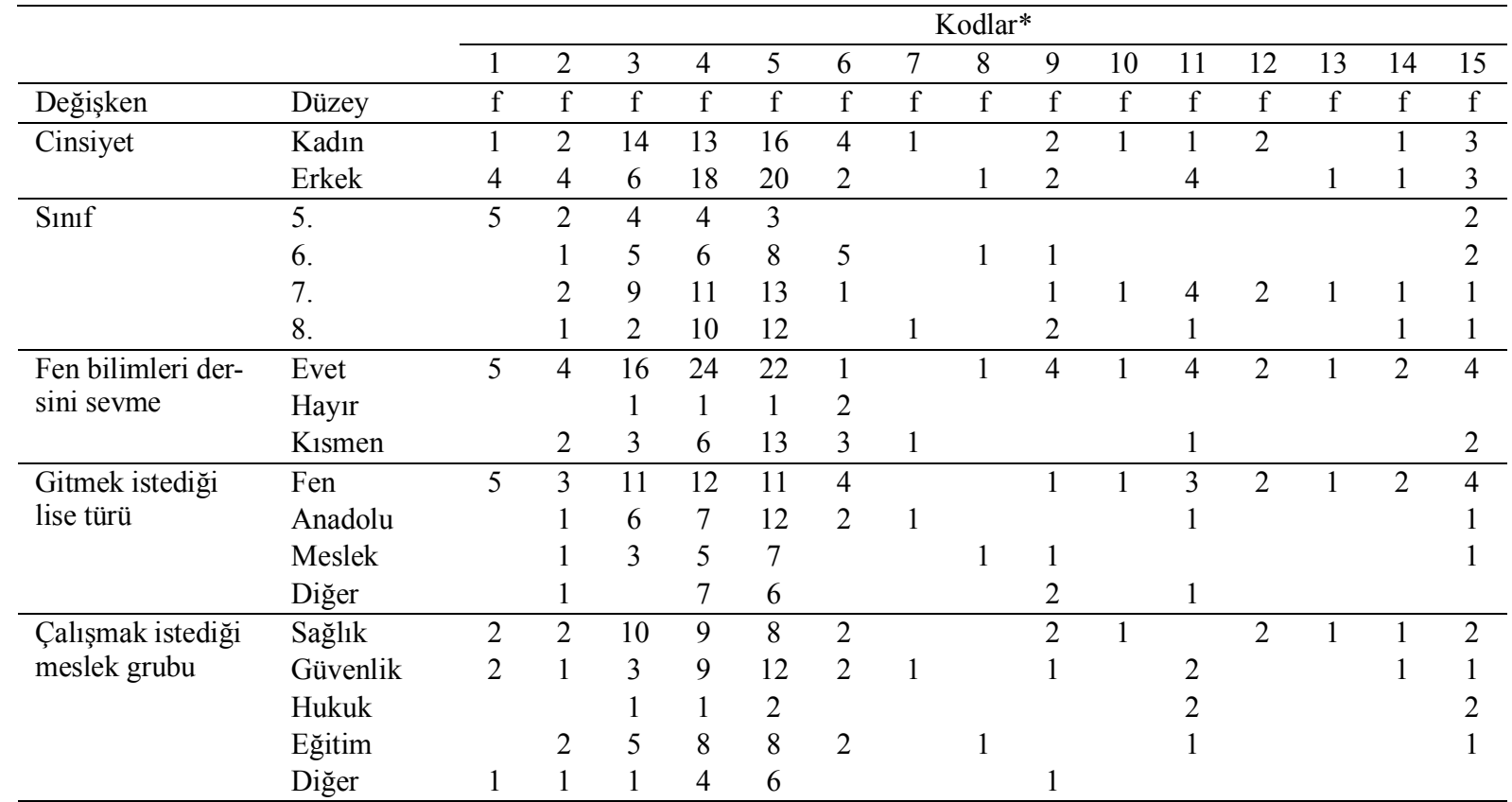

(*)1- Merak etme; 2-İsteme; 3-Bilgilenme; 4-Sevme; 5-Eğlenme, heyecanlanma; 6-Kendimi geliştirme; 7-Motivasyonu arttırma; 8-Öğretmenler tarafından beğenilme; 9-Grupla çalışmayı öğrenme; 10-Araştırma yapmayı öğrenme; 11-İnsanlığa faydalı olma; 12-İstediği projeyi yapma; 13-Derslere odaklanma; 14-Boş vakti doldurma; 15-Diğer.

Tablo 3'de YBO öğrencilerin proje hazırlamayı isteme nedenlerine yönelik görüş ve düşünceleri değişkenler açısından incelendiğinde değişkenler farklı olsa da görüş ve düşüncelerinin benzer olduğu görülebilir. Tüm değişkenlere göre öğrencilerin bilgilenmek, sevmek, eğlenmek ve heyecanlanmayla ilgili görüşlerinin diğer görüşlere oranla daha fazla olduğu belirlenmiştir. Cinsiyete göre her iki gruptaki öğrenciler en fazla eğlenmek ( $\mathrm{f}=36)$ için proje hazırlamayı istemektedir. Kadın öğrenciler proje hakkında bilgilenme istekleri ( $\mathrm{f}=14)$ erkek öğrencilerden $(\mathrm{f}=6)$ daha fazladır. Beşinci sınıf öğrencileri merak ettikleri $(\mathrm{f}=5)$ için isterken altıncı $(\mathrm{f}=8)$, yedinci $(\mathrm{f}=13)$ ve sekizinci sınıftaki ( $\mathrm{f}=12)$ öğrenciler daha çok eğlenmek için istemektedir. Fen bilimleri dersini seven öğrenciler sevmek ( $\mathrm{f}=24)$, eğlenmek $(\mathrm{f}=22)$ ve bilgilenmek $(\mathrm{f}=16)$ için istemektedir. Fen lisesine gitmek isteyen öğrencilerin çoğu bilgilenmek ( $\mathrm{f}=11)$, sevmek ( $\mathrm{f}=12$ ) ve eğlenmek ( $\mathrm{f}=11)$ için isterken Anadolu lisesine gitmek isteyen öğrenciler daha çok eğlenmek ( $\mathrm{f}=12)$ için istemektedir. İleride sağlık alanında çalışmak isteyen öğrenciler bilgilenmek $(\mathrm{f}=10)$, sevmek ( $\mathrm{f}=9)$ ve eğlenmek $(\mathrm{f}=8)$ için isterken güvenlik alanında sevmek $(\mathrm{f}=9)$ ve eğlenmek için $(\mathrm{f}=12)$ 
istedikleri, eğitim alanında öğretmenlik mesleğini tercih eden öğrenciler de sevmek (f=8) ve eğlenmek $(f=8)$ için proje hazırlamayı istemektedir.

Tablo 4. YBO öğrencilerin proje hazırlamayı istememe nedenlerine yönelik görüşlerinden oluşturulan kodların değişkenlere göre frekansları

\begin{tabular}{|c|c|c|c|c|c|c|c|c|}
\hline & & \multicolumn{7}{|c|}{ Kodlar* } \\
\hline & & 1 & 2 & 3 & 4 & 5 & 6 & 7 \\
\hline Değişken & Düzey & $\mathrm{f}$ & $\mathrm{f}$ & $\mathrm{f}$ & $\mathrm{f}$ & $\mathrm{f}$ & $\mathrm{f}$ & $\mathrm{f}$ \\
\hline \multirow[t]{2}{*}{ Cinsiyet } & Kadın & 2 & 1 & 3 & 1 & 1 & 1 & \\
\hline & Erkek & 6 & & 3 & 1 & & & 1 \\
\hline \multirow[t]{4}{*}{ Sinif } & 5. & & & & & & & \\
\hline & 6. & 3 & & 1 & & 1 & 1 & \\
\hline & 7. & 4 & & 3 & 1 & & & 1 \\
\hline & 8. & 1 & 1 & 2 & 1 & & & - \\
\hline \multirow{3}{*}{$\begin{array}{l}\text { Fen bilimleri dersini } \\
\text { sevme }\end{array}$} & Evet & 2 & & 3 & 2 & & & 1 \\
\hline & Hayır & & & & & & & \\
\hline & Kismen & 6 & 1 & 3 & & 1 & 1 & \\
\hline \multirow[t]{4}{*}{ Gitmek istediği lise türü } & Fen & 3 & & 1 & 1 & & 1 & - \\
\hline & Anadolu & 1 & & 4 & 1 & & & 1 \\
\hline & Meslek & 1 & & & & 1 & & \\
\hline & Diğer & 3 & 1 & 1 & & & & \\
\hline \multirow{5}{*}{$\begin{array}{l}\text { Çalışmak istediği mes- } \\
\text { lek grubu }\end{array}$} & Sağlık & 1 & & 3 & 1 & 1 & & \\
\hline & Güvenlik & 4 & & 2 & & & & 1 \\
\hline & Hukuk & & & & & & & \\
\hline & Eğitim & 3 & 1 & 1 & 1 & & 1 & \\
\hline & Diğer & & & & & & & \\
\hline
\end{tabular}

(*) 1-Zor, daraltıcı ve sıkıcı olduğunu düşünme; 2-Çekinme ve sosyal olmadığını düşünme; 3-Yeteneğinin olmadığını düşünme; 4-Proje yapmayı sevmeme; 5-Aklıma yeni fikirler gelmeme; 6-Bilgisi olmama; 7-Diğer.

Tablo 4'de Tablo 3'de olduğu gibi değişkenler farklı olsa da öğrencilerin proje hazırlamayı istememe nedenlerinin benzer ve frekansların düşük olduğu tespit edilmiştir. Öğrencilerin tüm değişkenlere göre proje hazırlamayı istememe nedenleri arasında zor, daraltıcı ve sıkıcı olmasının yanında yeteneğinin bulunmadığını düşünen öğrencilerde bulunmaktadır. Erkek öğrenciler $(\mathrm{f}=6)$ kadın öğrencilerden $(\mathrm{f}=2)$ daha fazla proje hazırlamanın zor, daraltıcı ve sıkıcı olduğunu düşünürken yeteneklerinin olmadığını düşünen kadın ve erkek öğrencilerin aynı (f=3) olduğu belirlenmiştir. Beşinci sınıf öğrencilerinin hepsi proje hazırlamak isterken diğer sınıflarda istemeyen öğrenciler bulunmaktadır. Fen lisesine gitmek isteyen öğrenciler ( $\mathrm{f}=3)$ proje hazırlamanın zor, daraltıcı ve sıkıcı olduğunu düşünürken Anadolu lisesine gitmek isteyen $(\mathrm{f}=4)$ öğrenciler yeteneğinin olmadıklarını düşünmektedir. Güvenlik $(f=4)$ ve eğitim ( $f=3$ ) alanlarında çalışmak isteyen öğrenciler proje hazırlamanın zor, daraltıcı ve sıkıcı olduğunu düşünürken sağlık ( $\mathrm{f}=3$ ) ve güvenlik $(\mathrm{f}=2$ ) alanında çalışmak isteyen öğrenciler yeteneklerinin bulunmadığını düşünmektedir.

Öğrencilerin proje hazırlamayı isteme ve istememe nedenlerine yönelik görüşlerinden bazı alıntıları aşă̆ıda verilmiştir:

Ö3: "Daha çok bilgi edinmek, icat yapmayı öğrenmek ve eğlenceli bulduğum için"

Ö10: "Proje yapmayı merak ediyorum. Proje yapmayı çok seviyorum."

Ö24: "Hiçbir bilgim olmadığı için proje yapmak istemiyorum."

Ö25: "Ben yapabileceğimden emin değilim ve yapamam."

Ö27: "Çok sıkıcı yani bana göre olmadığını düşünüyorum bu yüzden proje yapmak istemiyorum.”

Ö37: "Biz proje yaptıkça yeni şeyler öğreniyoruz ve proje yapmak eğlenceli."

Ö59: "Projeye katıldı̆̆ımızda insanlarla daha yakın oluyoruz hem de insanlara bir şey söylemek istiyoruz."

Ö64: "Evet çünkü bütün insanların zihninde bir proje vardır ve bunları gerçekleştirmek ister benim de gerçekleştirmek istediğim projeler olabilir bu yüzden proje yapmak istiyorum"

Ö78: "Proje yaparak daha iyi bir bakış açısı ile derslerimize odaklanmamız artar 
Ö94: "Çünkü hem arkadaş ortamını arttırıyor hem de hırs veriyor, sabır veriyor. Bir de o konu zevkliyle insana zevk veriyor."

Ö98: “TÜBİTAK proje alıp orada bir belgem olmasını isterim daha önce hiç almadım o yüzden”

Ö99: "Katıldığım etkinlikleri seviyorum ve çok severek katıllyorum. Bu şekilde ben katıldığım etkinliklerden bir şeyler öğreniyorum ne kadar yetenekli olduğumu bu sayede görebiliyorum."

Ö115: "Projeleri ilginç bulduğum ve bana zevk verdiği için"

Ö119: Projeler genellikle arkadaşlarım ve öğretmenimle olduğundan proje yapmayı seviyorum projeleri arkadaşlarımla beraber yaptığımızdan arkadaşlarımla daha güçlü arkadaşlığımız oluyor, Birbirimize ihtiyacımız olduğunu anlıyoruz eğlenceli aktivite olduğunu sanıyorum."

\section{3. Ü̧̧üncü alt probleme ilişskin bulgular}

YBO öğrencilerin proje eğitimi alma istekleriyle ilgili görüş ve düşüncelerinin değişkenlere göre frekansları Tablo 5-6'da verilmişsir.

Tablo 5. YBO öğrencilerin proje eğitim almayı isteme nedenlerine yönelik görüşlerinin değişkenlere göre frekanslar1

\begin{tabular}{|c|c|c|c|c|c|c|c|c|c|c|c|c|c|}
\hline & & \multicolumn{12}{|c|}{ Kodlar* } \\
\hline & & 1 & 2 & 3 & 4 & 5 & 6 & 7 & 8 & 9 & 10 & 11 & 12 \\
\hline Değişken & Düzey & $\mathrm{f}$ & $\mathrm{f}$ & $\mathrm{f}$ & f & f & $\mathrm{f}$ & $\mathrm{f}$ & $\mathrm{f}$ & f & $\mathrm{f}$ & f & $\mathrm{f}$ \\
\hline \multirow[t]{2}{*}{ Cinsiyet } & Kadın & 3 & 11 & 11 & 8 & 5 & 15 & 2 & & 2 & 2 & 1 & \\
\hline & Erkek & 14 & 10 & 9 & 8 & 5 & 9 & 1 & 2 & & & & 1 \\
\hline \multirow[t]{4}{*}{ Sinif } & 5. & 2 & 6 & 2 & 1 & & 4 & 1 & & & & & \\
\hline & 6. & 5 & 3 & 5 & 2 & 3 & 6 & & 1 & 1 & 1 & & \\
\hline & 7. & 6 & 6 & 11 & 7 & 4 & 7 & 2 & & & & 1 & 1 \\
\hline & 8. & 4 & 6 & 2 & 6 & 3 & 7 & & 1 & 1 & 1 & & \\
\hline \multirow[t]{3}{*}{ Fen bilimleri dersini sevme } & Evet & 12 & 16 & 13 & 11 & 8 & 16 & 1 & 1 & & 1 & 1 & 1 \\
\hline & Hayır & & & 2 & & & 1 & & 1 & & & & \\
\hline & Kismen & 5 & 5 & 5 & 5 & 2 & 7 & 2 & & 2 & 1 & & \\
\hline \multirow[t]{4}{*}{ Gitmek istediği lise türü } & Fen & 9 & 12 & 11 & 8 & 4 & 10 & 1 & & 1 & 1 & 1 & \\
\hline & Anadolu & 3 & 5 & 4 & 6 & 5 & 6 & 1 & 1 & & & & 1 \\
\hline & Meslek & 2 & 1 & 3 & 2 & & 4 & & 1 & & & & \\
\hline & Diğer & 3 & 3 & 2 & & 1 & 4 & 1 & & 1 & 1 & & \\
\hline \multirow[t]{5}{*}{ Çalışmak istediği meslek grubu } & Sağlık & 2 & 6 & 6 & 5 & 3 & 8 & 2 & & 1 & 1 & 1 & \\
\hline & Güvenlik & 9 & 3 & 2 & 5 & 2 & 7 & & 2 & & & & 1 \\
\hline & Hukuk & 5 & & 1 & 1 & & & & & & & & \\
\hline & Eğitim & & 8 & 10 & 4 & 4 & 8 & 1 & & 1 & 1 & & \\
\hline & Diğer & 1 & 4 & 1 & 1 & 1 & 1 & & & & 1 & & \\
\hline
\end{tabular}

(*) 1-Proje aşamaları hakkında bilgi edinme; 2-Yeni bilgiler öğrenme; 3-Kendimi geliştirme; 4-Eğlenme;

5-Başarılı olma; 6-Proje yapmayı isteme/sevme; 7-Merak etme; 8-Yeni tasarımlar oluşturma; 9-Proje yaparken kendisini iyi hissetme; 10-Proje hakkındaki görüşlerini ifade etme; 11-Boş vakitlerini değerlendirme; 12-Bilimi daha iyi öğrenme.

Tablo 5'de değişkenler farklı olsa da öğrencilerin proje eğitimi alma isteklerinin benzer ve belli görüşlerin daha fazla olduğu tespit edilmiştir. Kadın öğrencilerin proje eğitimi almayı isteme nedenleri arasında proje yapmak $(\mathrm{f}=15)$ ve sevdikleri $(\mathrm{f}=15)$ için isterken erkek öğrencilerin projenin aşamalarını öğrenmek $(\mathrm{f}=14)$ için istedikleri belirlenmiştir. Beşinci sınıf öğrencileri yeni bilgiler öğrenmek $(f=6)$, altıncı $(f=6)$ ve sekizinci sınıftaki öğrencileri proje yapmak $(\mathrm{f}=7)$ için proje eğitim almak isterken yedinci sınıf öğrencileri kendilerini geliştirmek $(\mathrm{f}=11)$ için istemektedir. Fen bilimleri dersini seven öğrenciler yeni bilgiler öğrenmek $(f=16)$, proje yapmak $(f=16)$ için eğitim almayı istemektedir. Fen lisesine gitmek isteyen öğrenciler projenin aşamalarını öğrenmek ( $\mathrm{f}=9)$, yeni bilgiler öğrenmek ( $\mathrm{f}=12)$, kendilerini geliştirmek ( $\mathrm{f}=11)$, eğlenmek $(\mathrm{f}=8)$, proje yapmayı istedikleri ve sevdikleri $(\mathrm{f}=10)$ için istemektedir. Sağlık alanında çalışmak isteyen öğrenciler proje yapmayı istedikleri ve sevdikleri ( $\mathrm{f}=9)$ için isterken güvenlik alanında çalışmak isteyen öğrenciler projenin aşamalarını öğrenmek ( $\mathrm{f}=9$ ) için istemektedir. Eğitim alanında öğretmen olmak isteyen öğrenciler kendilerini geliştirmek ( $\mathrm{f}=10)$ için proje eğitimi almayı istemektedir.

Tablo 6'da öğrencilerin proje eğitimi almayı istememe nedenlerine yönelik görüşleri tüm değişkenler açısından incelendiğinde değişkenler farklı olsa da benzer görüşlerin olduğu, çok az sayıda öğrencinin eğitim almak istemediği ve proje yapmayı düşünmedikleri için istemedikleri belirlenmiş̧ir. 
Tablo 6. YBO öğrencilerin proje eğitimi almayı istememe nedenlerine yönelik görüşlerinin değişkenlere göre frekansları

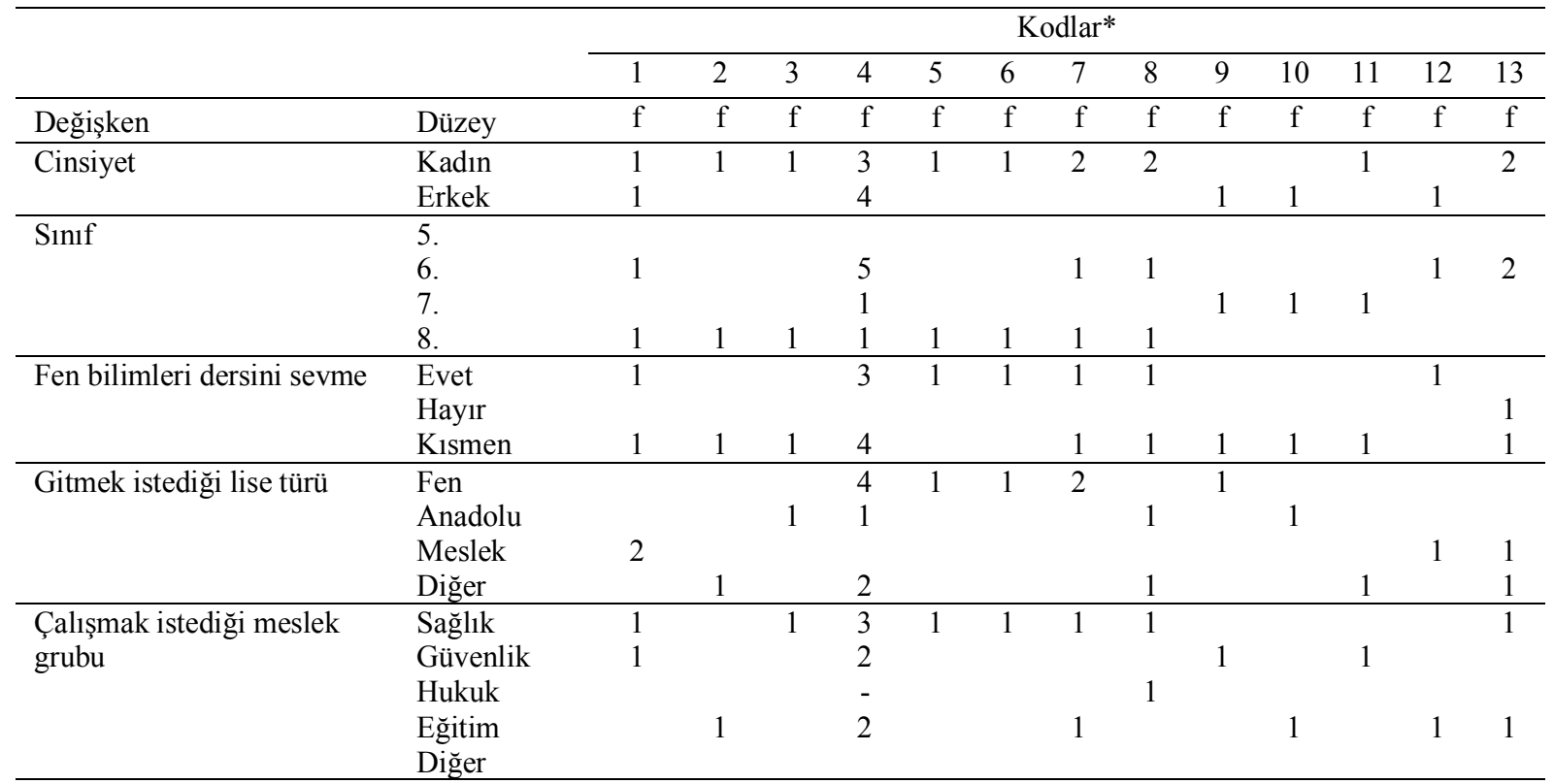

(*) 1-Projeyi başkalarına anlatmayacağını düşünme; 2-Sosyal olmadığı düşünme; 3-Çekinme; 4-İstememe,/sevmeme; 5Eğlenceli bulmama; 6-Yeteneğinin olmadığını düşünme; 7-Kendimi geliştirmek istememe; 8-Ne yapacağını bilememe; 9İyi bir şey olmadığını düşünme; 10-Daha önce proje yapmama;

11-Zor olduğu düşünme; 12-Küęük düşmekten korkma; 13-Aklına yeni fikirler gelmeyeceğini düşünme.

Öğrencilerin proje eğitimi almayı isteme ve istememe nedenlerine yönelik görüşlerinden bazı alıntıları aşă̆ılda verilmiştir:

Ö9: "Eğitimi güzel olarak düşünüyorum kesinlikle güzel olacak eğitimde proje yapmak istiyorum."

Ö31: "Projeye katılırsam çok yüksek puan alır karneme geçtiği için karnem iyi olur diye düşündüm.”

Ö32: "Projeleri seviyorum ama bazı projeler zor oluyor ve yapamaya biliyoruz. O yüzden kendimi geliştirmek istiyorum."

Ö45: "Çok iyi bir proje yapmak fen lisesine gitmek ve çok becerikli olmak ve en iyi projeyi yapmak ve en ünlü birisi olmak."

Ö61: "Merak ettiğim her şeyi öğrenmek ve merakımı gidermek istiyorum.”

Ö62: "Projeyi eğlenceli buluyorum bilgilerim artıyor ve kendimi geliştiriyorum."

Ö63: "Boş vakitlerimi dolu ve faydalı bir şekilde geçirebilecek bir firsat benim için."

Ö64: "Evet çünkü proje eğitimi alırsam kendimi yapacağım projede geliştirmiş olurum.”

Ö65: "Daha önce hiç katılmadım öğrenmek istiyorum. Çünkü bana daha değişik yerlerde de ihtiyacıma yarayacak. Belki bir meslek sahibi olduğumda bana proje yaptıracaklar."

Ö84: "Derslerde daha başarılı olabiliriz notlarımız yüksek olabilir."

Ö91: "İyi bir şey olduğunu düşünmüyorum o yüzden katılmıyorum."

Ö98: "Ben orada yer almak çok isterim. Hatta bu yüzden hocalarıma bile yalvardım ben oradan bir belge almak bile benim için bir başarı..."

Ö119: "Burada gördüğüm eğitimle İlerideki eğitim-öğretim hayatıma katkı sağlayabilir. Bu eğitime katıldığımda projelere olan İlgim değişebilir, daha çok projelerde yer almak isteyebilirim. Meslek sahibi olduğumda Mesleğimle ilgili projeler verebilirim."

\subsection{Dördüncü alt probleme ilişkin bulgular}

YBO öğrencilerin proje hazırlama ve eğitim almanın onlara sağlayacağı yararlara yönelik görüş ve düşüncelerinin değişkenler açısından frekanslarının değişimi Tablo 7'de verilmiştir. 
Tablo 7. YBO öğrencilerin proje hazırlama ve eğitim almanın sağladığı yararlara yönelik görüşlerinin değişkenlere göre frekansları

\begin{tabular}{|c|c|c|c|c|c|c|c|c|c|c|c|}
\hline & & \multicolumn{10}{|c|}{ Kodlar* } \\
\hline & & 1 & 2 & 3 & 4 & 5 & 6 & 7 & 8 & 9 & 10 \\
\hline Değişken & Düzey & $\mathrm{f}$ & $\mathrm{f}$ & $\mathrm{f}$ & $\mathrm{f}$ & $\mathrm{f}$ & $\mathrm{f}$ & $\mathrm{f}$ & $f$ & $\mathrm{f}$ & $\mathrm{f}$ \\
\hline \multirow[t]{2}{*}{ Cinsiyet } & Kadın & 20 & 26 & 8 & & 2 & 3 & 1 & 2 & 1 & 5 \\
\hline & Erkek & 17 & 13 & 17 & 6 & 2 & 5 & 2 & 1 & 9 & 13 \\
\hline \multirow[t]{4}{*}{ Sinıf } & 5. & 11 & 1 & 1 & 1 & 2 & 3 & & 2 & 7 & 3 \\
\hline & 6. & 3 & 12 & 8 & 1 & & & & 1 & 2 & 4 \\
\hline & 7. & 11 & 15 & 12 & 3 & 1 & 2 & 2 & & & 5 \\
\hline & 8. & 12 & 11 & 4 & 1 & 1 & 3 & 1 & & 1 & 6 \\
\hline \multirow{3}{*}{$\begin{array}{l}\text { Fen bilimleri } \\
\text { dersini sevme }\end{array}$} & Evet & 26 & 21 & 21 & 3 & 2 & 8 & 2 & 2 & 8 & 10 \\
\hline & Hayır & 2 & 2 & & 1 & 1 & & & & & 2 \\
\hline & Kismen & 9 & 16 & 4 & 2 & 1 & & 1 & 1 & 2 & 6 \\
\hline \multirow{4}{*}{$\begin{array}{l}\text { Gitmek istediği } \\
\text { lise türü }\end{array}$} & Fen & 16 & 20 & 12 & 2 & 2 & 7 & 2 & 2 & 4 & 4 \\
\hline & Anadolu & 9 & 10 & 6 & 4 & & & & & 3 & 7 \\
\hline & Meslek & 8 & 3 & 3 & & 2 & & 1 & & 1 & 4 \\
\hline & Diğer & 4 & 6 & 4 & & & 1 & & 1 & 2 & 3 \\
\hline \multirow{5}{*}{$\begin{array}{l}\text { Çalışmak iste- } \\
\text { diği meslek } \\
\text { grubu }\end{array}$} & Sağlık & 12 & 14 & 6 & 1 & 1 & 4 & 1 & 2 & 1 & 3 \\
\hline & Güvenlik & 12 & 8 & 8 & 3 & 1 & 1 & & 1 & 6 & 8 \\
\hline & Hukuk & 1 & 4 & 3 & & & & 1 & & & - \\
\hline & Öğretmen & 10 & 11 & 8 & 1 & 2 & & & & & 7 \\
\hline & Diğer & 2 & 2 & & 1 & & 3 & 1 & & 3 & \\
\hline
\end{tabular}

(*) 1-Yeni bilgiler öğreneceği; 2-Kendini geliştirebileceği; 3-Derslerinde ve kariyerinde başarılı olacağı; 4-Eğlenceli, heyecanlı bir ortam sağlayacağı; 5-Proje yapmayı isteme/sevmeyi artıracağı; 6-Projenin aşamalarını öğreneceği; 7-İnsanlığa faydalı olabileceği; 8-İcat, tasarım yapmayı sağlayabileceği; 9-Kendini iyi hissedeceği; 10-Diğer.

Tablo 7'de değişkenler farklı olsa da YBO öğrencilerin proje hazırlama ve eğitim almanın onlara sağlayacağı yararlara yönelik görüşlerinin benzer olduğu ve belli görüşlerin daha fazla öne çıktığı görülmektedir. Kadın öğrenciler yeni bilgiler öğreneceğini ( $\mathrm{f}=20)$ ve kendini geliştirebileceğini ( $\mathrm{f}=26)$ düşünürken erkek öğrenciler yeni bilgiler öğreneceğini ( $\mathrm{f}=17)$, kendini geliştirebileceğini ( $\mathrm{f}=13)$, derslerinde ve kariyerinde başarılı olacağını $(\mathrm{f}=17)$ düşünmektedir. Beşinci sınıf öğrencileri yeni bilgiler öğreneceğini ( $\mathrm{f}=11)$, altıncı sınıf öğrencileri kendilerini geliştireceğini ( $\mathrm{f}=12)$, yedinci sınıf öğrencileri yeni bilgiler öğreneceğini $(\mathrm{f}=11)$, kendini geliştirebileceğini $(\mathrm{f}=15)$, derslerinde ve kariyerinde başarılı olacağını ( $f=12)$, sekizinci sınıf öğrencileri yeni bilgiler öğreneceğini ( $f=12)$ ve kendilerini geliştireceğini ( $\mathrm{f}=11$ ) düşünmektedir. Fen bilimleri dersini seven öğrenciler yeni bilgiler öğreneceği $(\mathrm{f}=26)$, kendini geliştirebileceği $(\mathrm{f}=21)$, derslerinde ve kariyerinde başarılı olacağını $(\mathrm{f}=21)$ düşündükleri tespit edilmiştir. Fen lisesine gitmek isteyen öğrenciler yeni bilgiler öğreneceğini ( $f=16)$, kendini geliştirebileceğini $(\mathrm{f}=20)$, derslerinde ve kariyerinde başarılı olacağını $(\mathrm{f}=12)$ düşünürken Anadolu lisesine gitmek isteyen öğrenciler yeni bilgiler öğreneceğini $(\mathrm{f}=9)$, kendini geliştirebileceğini $(\mathrm{f}=10)$ düşünmektedir. Sağlık ve eğitim alanında çalışmak isteyen öğrenciler yeni bilgiler öğreneceğini ( $f=12$ ve 10$)$ ve kendini geliştirebileceğini ( $f=14$ ve 11) düşünürken güvenlik alanında çalışmak isteyen öğrenciler yeni bilgiler öğreneceğini ( $\mathrm{f}=12)$ düşünmektedir.

Ögrencilerin proje hazırlama ve eğitim almanın onlara să̆layacă̆ı yararlara yönelik alıntılarından bazıları aşağıda verilmiştir:

Ö1: "Mesela çok güzel bir araba yaparım."

Ö30: "Dünyada neyin az neyin çok neyin gereksiz olduğunu proje yaparak anlayarak hem de ilerideki projelerimin ne hakkında olacağını bulabilirim."

Ö35: "İyi bir meslek almamız derslerimizin iyi olması başarılı olması”"

Ö42: “Öğretmenimiz bize aferin der sözlümüzü yükseltir.”

Ö46: "Daha kolay öğrenmemi ve sorumluluklarımı yerine getirmemi sağlayabilir."

Ö50: "Proje yaparak kendini çok iyi hissedersin ve hayalin proje yaparak çok eğlenceli proje düşünmeye başlarız"

Ö52: "Bilimsel şeyleri öğrenip fen bilimleri dersimizde uygulamak yeni şeyler keşfedip öğreniyoruz"

Ö75: "Derslerde başarılı olmamızı sağlar ve bilmediğimiz şeyleri öğrenmeye yararlı olur." 
Ö88: “İleride belki bununla ilgili bir iş ve görev sahibi olabiliriz

Ö94: "Zihnimizi canlandırır, düşünce yollarımızı geliştirir"

Ö102: "Her şeyi daha iyi anlayabilmem için gelen misafirlere karşı açık sözlü olmam, kendimi tanıtmam. Bu yüzden katılmak isterdim."

Ö108: "Bir ş̧eyler öğrenebilir belki, bana fayda sağlayabilir insanların gelecekte nelere ihtiyaç duyacağını tahmin ederek insanlı̆̆a faydalı bir şeyler yapabiliriz"

Ö115: "Hayatta bir tecrübe edinmiş olurum Belki hayatımda güzel anılar küçük çaplı başarılar elde ederim. Kim bilir?"

Ö116: "Genel kültürüm gelişir ve hayatta başarılı olacağımı zannediyorum”

Ö117: "Mesela alan da yeni bir bilgi öğrenmek için eğlenmek için o hissi o duyguyu yaşamak için"

Ö119: "Sosyal bir insan olabilirim gördüğüm eğitimle, ileride eğitim öğretimimde daha başarılı olabilirim.”

Ö121: proje yaparsam o projelerden bir şeyler öğrenirdim ve arkadaşlarımla paylaşırdım.”

\section{Tartışma, sonuç ve öneriler}

Öğretme-öğrenme sürecinde öğrenciyi merkeze alan ve gerçek yaşamda yaşanmış bir problemi veya herhangi bir uygulamayı eğitim sisteminin içerisine dâhil eden PTÖ, öğrencileri geleneksel öğrenmede olduğu gibi pasif bir öğrenen değil, çevresiyle birebir etkileşim halinde olan birey konumuna getirmektedir. Öğrencilere bilgiyi vermek ve onları ezbere öğrenmeye sürüklemek yerine onlardan bilgiye ulaşma, bilgiyi anlama, yorumlama, üretme ve bunları günlük yaşamda sürdürülebilir hale getirmelerini beklemektedir (Olgun, Yavuz ve Yokuş, 2019). Bu aç1dan bakıldığında YBO öğrencilerinin \%74,0'ü proje hazırlamayı, \%78,0'i projeyle ilgili eğitim almayı ve \%69,1'i her ikisini birlikte yapmayı küçük yaşta istemeleri gelecek açısından ümit verici olduğu söylenebilir. Akay (2013), Mersin'de TÜBİTAK 4004 kapsamında ortaokul öğrencileriyle farklı bilimsel etkinliklerin yapıldığı projenin küçük yaşta bilime ve bilimsel bilgiye katkısının olduğunu, yaparak yaşayarak aktif öğrenmeyi destekleyen bir süreci kapsadığını, öğrencilerin eğlenerek bilimsel bilgiyi öğrendiklerini ve gelecekte yapacakları bilimsel çalışmalarda onlara yol gösterici olacă̆ını belirtmiştir.

YBO öğrencilerin proje hazırlama ve eğitim alma isteklerinin benzer olması (Tablo 2-7) onların ailelerinden uzakta yatılı öğrenim gördükleri için sosyal çevrelerinin benzer olduğunu ve birbirlerini etkilediklerini, proje ile sosyal çevrelerinin sınırlarını genişletmek istediklerini ve bunu bir firsat olarak gördüklerini, monoton bir yaşam sürdüklerini ve derslerin dışında boş zamanlarını değerlendirecek, motivasyonlarını artıracak ve gelişimlerine katkıda bulunacak aktivitelerle uğraşmaya meyilli olduklarını düşündürmektedir. Akkanat (2020), Merzifon' da TÜBİTAK 4007 kapsamında düzenlenen bilim şenliği etkinliğine katılan ortaokul öğrencilerin etkin katılım sağladıklarını, bilim öğrenmeyle ilgili motivasyonlarının arttığını ve bilim şenliklerine karşı olumlu tutumlar geliştirdiklerini belirtmiştir.

YBO öğrencilerin proje hazırlama ve eğitim alma isteklerinin nedenlerine yönelik olumlu görüşlerinin olumsuz görüşlerinden fazla ve benzer olması onların proje konusunda bilinçli olduklarını, büyük çoğunluğunun daha önce böyle bir öğretim süreci yaşamadıklarını ancak yaşamak istediklerini düşündürmektedir. Atalmış, Selçuk ve Ataç'ın (2018), TÜBİTAK 4006 projelerinin öğrencilerin bilişsel becerilerini artırdığını, sosyal ve kültürel etkinliklere katılma isteği uyandırdığını, özgüvenlerinin arttığını, okuldaki bilişsel ve duyuşsal davranışlarında pozitif gelişme sağladığını ve disipline ettiğini açıklamışlardır.

YBO öğrencilerin cinsiyete göre her iki gruptaki öğrencilerin eğlenmek için proje hazırlamak istemeleri onların yatılı öğrenimleri sırasında bir şeylerle kendilerini meşgul etmek, meşgul ederken kendilerini donanımlı yetiştirecek etkinlikler yapmak ve etkinliklerde eğlenmek istediklerini düşündürmektedir. Kadın öğrencilerin proje hakkında bilgilenmek için proje hazırlama istekleri erkek öğrencilerin yaklaşık iki buçuk kat daha fazla olması kadınların erkeklere oranla daha düzenli ders çalıştıklarını ve boş zamanlarında daha fazla bilgi edinmek için kaynak araştırdıklarını düşündürmektedir. Erkek öğrencilerin proje hazırlamayı istememe nedenleri arasında zor, daraltıcı ve sıkıcı olduğuna yönelik görüşlerinin kadın öğrencilerden daha fazla (Tablo 4) olması bu düşünceyi desteklemektedir. Kadın öğrenciler proje eğitimi almayı proje çalışmalarını sevdikleri için isterken erkek öğrenciler projenin aşamalarını öğrenmek için istemeleri (Tablo 5) kadın öğrencilerin erkek öğrencilere oranla daha fazla proje çalışmaları içinde olduklarını ve erkek öğrencilerin eğitim aldıktan sonra daha bilinçli proje hazırlamak istediklerini düşündürmektedir. 
Projeyle ilgili yapılmış çalışmaların bazıları cinsiyete göre farkın anlamlı ve daha çok kadınlar lehine olduğu belirtirken bazılarında anlamlı fark olmadığı belirtilmektedir (Atik, 2009). Karasu (2012), sosyal bilgiler dersinde yapılan proje çalışmalarına yönelik altıncı ve yedinci sınıflardaki öğrencilerin görüşleri ile cinsiyetleri arasında anlamlı fark olurken öğretmenlerin görüşlerinde olmadığını, eğitim fakültesi mezunu öğretmenlerin proje çalışmalarına yönelik görüşlerinin daha olumlu olduğunu belirtmiştir.

YBO öğrencilerinden beşinci sınıf öğrencilerinin tümü proje hazırlamayı merak ettikleri için isterken diğer sınıflardaki öğrenciler daha çok eğlenmek için istemektedir. Bu bulgu beşinci sınıf öğrencilerinin boş zamanlarının diğer sınıftaki öğrencilerden fazla olduğu, içinde bulundukları duruma henüz alışamadıkları, aile özlemini daha çok hissettikleri, aile özlemini hafifletmek ve kendilerini meşgul etmek için merak ettikleri projeleri hazırlamak istediklerini düşündürmektedir. Proje hazırlamak istemeyen öğrenciler az olsa da altı, yedi ve sekizinci sınıflarda olduğu, öğrencilerin proje hazırlama ve eğitim alma isteklerinin birbirine benzediği ve daha çok kendilerini geliştirmeye yönelik görüşleri içerdiği söylenebilir. Karasu (2012), sosyal bilgiler dersinde yapılan proje çalışmalarıyla ilgili altıncı ve yedinci sınıflardaki öğrencilerin görüşlerinin sınıf düzeyleri açısından anlamlı fark olmadığını belirtmiş̧ir.

Öğrencilerin fen bilimleri dersini sevme düzeyleri (Tablo 1) ile proje hazırlama ve eğitim alma isteklerinin paralellik göstermesi fen bilimleri öğretmenlerinden kaynaklanabileceğini düşündürmektedir. YBO öğrencilerin proje hazırlama ve eğitim alma isteklerinin nedenlerine yönelik görüşleri arasında öğretmenlerini sevdikleri, onlara kendilerini beğendirmek istedikleri vb. görüşlerinin olması öğrencilerin yatılı öğrenim gördüklerinden ailelerinden çok öğretmenleriyle birlikte oldukları için öğretmenleri ve arkadaşlarıyla iletişimlerini artıracaklarının farkında olduklarını düşündürmektedir. Nitekim Quek vd. (2007), proje hazırlama süreci açık uçlu bir öğrenme ortamı sağladığı için öğretmen-öğrenci ve öğrenci-öğrenci etkileşimini artırmaktadır. Öğrencilerin gelişimlerinde öğretmenlerin rolünün önemli olduğu, onlara rol model olacak kişiler arasında yer aldığı ve öğretmenin başarısı öğrencinin başarısına yansıdığı (Çelikten, Şanal ve Yeni, 2005; Gsukey \& Sparks, 1996; Oktay, 1991; Sabuncuoğlu, 2016; Sünbül, 1996) düşünüldüğünde öğretmenlerin mesleki gelişimleri öğrencilerin başarısını etkilemektedir.

Fen bilimleri dersini seven öğrencilerin çoğunlukta olması ve proje denildiğinde akla gelen ilk disiplinin fen alanı (Acar, 2011; Aslan, 2009; Aydemir, 2019; Çakallıŏlu, 2008; Çıbık, 2006; İmer, 2008; Keser, 2008; Kızkapan, 2015; Köse, 2010; Özahioğlu, 2012; Özel, 2013; Türkmen, 2019) olması öğrencilerin fen alanlarıyla ilgili projeler yapmak istediklerini düşündürmektedir. Filiz ve Kocakülah (2020), 2002-2019 yılları arasında PTÖ ile ilgili yapılmış 82 çalışmayı incelediklerinde \%60 Fen Bilimleri, \%15 Biyoloji, \%7 Kimya ve \%6 Fizik alanında olduğunu, Fen Bilimleri alanında yapılan çalışmaların 2008-2011 yılları arasında yoğunlaştığını belirtmişlerdir. Ayrıca incelenen çalışmaların \%60'ının ilköğretim, \%8 ortaöğretim ve \%32 üniversite düzeyindeki öğrencilerle gerçekleştirildiğini açıklamışlardır.

Öğrencilerin gitmek istediği lise türünü kazanabilmelerine yardımcı olacak yetenek ve becerileri geliştirmek istedikleri için proje hazırlama ve eğitim almayı istedikleri söylenebilir. Ayrıca hedefledikleri kariyere ulaşmak adına gitmek istediği lise türünün önemli olduğu düşünülmektedir. Avc1, Özenir ve Yücel (2016), öğrencilerin projeyle ilgili deneyimleri bir üst öğrenim düzeylerine katkı sağladığını belirtmişlerdir. Demirhan (2002), özel bir okulda üçüncü sınıf Hayat Bilgisi dersinde gerçekleştirdiği çalışmasında öğrencilerin ulusal ve uluslararası projeler hazırlamak için proje eğitimi almaya istekli olduklarını belirtmiş̧ir.

YBO öğrencilerinin gitmek istedikleri lisenin en fazla $(\% 43,1)$ fen lisesi olması onların gidecekleri lisede diğer öğrencilerden farkını ortaya koyarak daha başarılı olmayı, yeni projeler tasarlamak ya da üretmek için proje hazırlama ve eğitim almak istediklerini düşündürmektedir. İmam hatip, vb. diğer liselere gitmek isteyen öğrenciler fen lisesine oranla az $(\% 15,4)$ olsa da proje hazırlama ve eğitim almayı isteyen öğrencilerin fazla $(\% 79,8)$ olması imam hatip liselerinde proje okullarının açılmasından kaynaklandığını düşündürmektedir. Bozkurt Altan, Üçüncüoğlu ve Zileli’nin (2019), YBO öğrencileriyle yapmış oldukları çalışmada öğrencilerin gitmek istedikleri lise türünün güzel sanatlar, spor ve Anadolu liselerinin olduğu, bir kısmının fen lisesi, sağlık meslek, meslek ve imam hatip liselerine gitmek istediklerini ve az sayıda öğrencinin STEM ile ilgili alanlara yöneldiklerini belirtmişlerdir.

YBO öğrencilerinin görüşlerinden gelecekte güvenlik alanında çalışmak isteyenlerin $(\% 30,9)$ diğer meslek gruplardan fazla olması ve yarı yapılandırılmış görüşmelerde vatanı düşmanlardan korumak için asker, polis olmak istediklerini belirtmeleri onların yakın zamanda yaşanan " 15 Temmuz Kalkışma Hareketi”nden etkilendiklerini ve üniforma giymek isteklerini düşündürmektedir. Karaer (2007), sekizinci sınıf öğrencilerin görüşlerinden hareketle çalışmak istedikleri meslek grubunun güvenlik ve sağlık vb. üniformalı meslek gruplarında olmasını öğrencilerin bir an önce çalışmak ve aile bütçesine faydalı olmak için istediklerini belirtmiştir. 
Öğrencilerin proje hazırlama ve eğitim almanın sağlayacağı yararlara yönelik görüş ve düşüncelerinin proje hazırlama ve eğitim alma isteklerinin nedenlerine yönelik görüş ve düşüncelerine paralellik göstermesi kendilerini çağın gereksinimlerini karşılayacak şekilde donanımlı yetişmek istediklerini ve proje yaptıklarında onlara neler kazandıracağının farkında olduklarını düşündürmektedir. Erkek öğrenciler proje yaptıklarında kadın öğrenciler gibi yeni bilgiler öğreneceklerini ve kendilerini geliştirebilecekleri gibi derslerinde ve kariyerinde başarılı olacaklarına inandıkları söylenebilir. Öğrencilerin sınıf düzeyi arttıkça proje çalışmaları öğrencilerin meraklarını gidermesinin yanında bilgi, beceri ve deneyimleme açışından gelişimlerine katkı sağlayacağının farkında oldukları düşünülmektedir. Öğrencilerin fen bilimleri dersini sevme, gitmek istediği lise ve çalışmak istediği meslek grubuyla ilgili görüşlerinin cinsiyet ve sınıf değişkenlerinde olduğu gibi proje hazırlama ve eğitimi almanın onlara sağlayacağı yararlarıyla ilgili bilgiye sahibi olduklarını ve bilinçli olarak proje hazırlamayı ve eğitim almayı istediklerini düşündürmektedir. $\mathrm{Bu}$ açıdan bakıldığında YBO öğrencileri ileride iş hayatına atıldıklarında geleneksel yöntemle yetişen öğrencilere göre daha deneyimli, kendine güvenen ve zorlukların üstesinden daha kolay gelebilecekleri düşünülmektedir.

Sonuç olarak, öğrencilerin büyük çoğunluğu günlük yaşamda karşılaştıkları problemlere çözüm bulmak, proje konusunda çekinceleri, korkuları olsa da donanımlı yetişmek istedikleri için proje hazırlama ve eğitim almak istedikleri söylenebilir. Öğrencilerin sınıf düzeyleri artsa da geleceğe yönelik görüş ve düşüncelerinin kendilerini geliştirmek adına olduğu, çoğunun fen lisesine gitmek ve ileride istedikleri meslekte çalışmak için donanımlı yetişmek istedikleri söylenebilir.

$\mathrm{Bu}$ sonuçlardan hareketle, öğrencilerin proje hazırlama ve eğitim alma isteklerini karşılayacak PTÖ yaklaşımına önem verilmesi, öğrencileri proje tasarlama veya üretmeye teşvik edilmesi, öğrencilere verilecek proje tabanlı eğitimler onların düzeylerine, ihtiyaçlarına, merak duygusunu giderecek şekilde olması ve düzenlenecek eğitimlerden tüm öğrencilerin faydalanabileceği şekilde planlanmasına özen gösterilmesi önerilmektedir.

\section{Yazarların katkı oranı beyanı}

Yazarlar makalenin veri toplama, veri analizi, raporlaştırma ve diğer aşamalarından eşit düzeyde sorumlu olduğunu beyan ederler.

\section{Çıkar Çatışması}

Bu çalışmada yazarlar tarafından herhangi bir çıkar çatışması belirtilmemiştir.

\section{Etik Kurul Onayı}

Bu araştırma T.C. Ondokuz Mayıs Üniversitesi Sosyal ve Beşeri Bilimler Etik Kurulunun 28.03.2019 tarih ve 3/2019-52 sayılı kararı ile etik açından uygun bulunmuştur. Tüm sorumluluk yazarlarına aittir.

\section{Kaynakça}

Acar, E. N. (2011). Proje tabanlı öğrenmenin fen bilgisi öğretmen adaylarının bilimsel süreç becerilerine ve biyolojiye yönelik tutumlarnna etkisi. Yüksek lisans tezi. Çanakkale Onsekiz Mart Üniversitesi Fen Bilimleri Enstitüsü, Çanakkale.

Akay, C. (2013). Ortaokul öğrencilerinin yaparak-yaşayarak öğrenme temelli TÜBiTAK 4004 bilim okulu projesi sonrası bilim kavramına yönelik görüşleri. Mersin Üniversitesi Eğitim Fakültesi Dergisi, 9(2), 326-338.

Akçöltekin, A. ve Akçöltekin, S. (2017). İlkokul ve ortaokul öğretmenlerinin bilimsel araştırmalar ve proje yarışmaları hakkındaki tutumlarını geliştirmeye yönelik eğitimin etkilerinin incelenmesi. Atatürk Üniversitesi Kazım Karabekir Eğitim Fakültesi Dergisi, 35, 252-273.

Akgül, E. (2011). Illköğretim 4. Sinıf öğrencilerine matematik dersinde "açılar” konusunun öğretilmesinde proje tabanlı öğretim yönteminin etkisinin incelenmesi. Yüksek lisans tezi. Marmara Üniversitesi Eğitim Bilimleri Enstitüsü, İstanbul.

Akın, D. (2016). 6. Sınıf sosyal bilgiler dersinde proje tabanlı ögrenmenin öğrencinin akademik başarısına ve derse karşı tutumuna etkisi. Yüksek lisans tezi. Fırat Üniversitesi Eğitim Bilimleri Enstitüsü, Elazığ.

Akkanat, Ç. (2020). TÜBITTAK 4007 bilim şenliği destekleme programı kapsamında gerçekleştirilen Merzifon bilim şenliğinin farklı yaş gruplarına göre değerlendirilmesi. Journal of Interdisciplinary Education: Theory and Practice, 2(2), 102-122.

Aslan, Ö. (2009). Proje tabanlı öğrenme yaklaşımının ilköğretim ögrencilerinin fen ve teknoloji dersine yönelik motivasyonlarına ve bilimin doğasını anlama düzeylerine etkisi. Yüksek lisans tezi. Hacettepe Ün. Sosyal Bilimleri Enstitüsü, Ankara.

Aslanides, C. D., Kalfa, V., Athanasiadou, S., Gianelos, Z. \& Karapatsias, V. (2016 September). Advantages, disadvantages and the viability of project-based learning integration in engineering studies curriculum: the Greek case. Paper presented at the meeting of 44th SEFI Conference, Finland. 
Atalmış, E. H., Selçuk, G. ve Ataç, A. (2018). TÜBİTAK 4006 projelerine ilişkin yönetici, yürütücü ve öğrenci görüşleri. Kırşehir Ĕ̌itim Fakültesi Dergisi, 19(3), 1999-2020.

Atik, C. (2009). İlköğretim fen ve teknoloji öğretiminde proje tabanlı öğrenme yaklaşımının ögrencilerin akademik başarıları üzerine etkisi. Yüksek lisans tezi. Süleyman Demirel Üniversitesi Fen Bilimleri Enstitüsü, Isparta.

Avcı, E. Özenir, S. ve Yücel, E. (2016). Ortaöğretim öğrencilerinin araştırma projeleri yarışmasına katılan öğrencilerin yarışma sürecindeki deneyimlerinin üniversite yarışmalarına yansıması. Uşak Üniversitesi Sosyal Bilimle Dergisi, 9(3), 1-21.

Ay, Ş. (2013). Öğretmen Adaylarının proje tabanlı öğrenme ve geleneksel öğretime ilişkin görüşleri. Hacettepe Üniversitesi Eğitim Fakültesi Dergisi, 28(28-1), 53-67.

Aydemir, A. (2019). Proje tabanlı öğrenme yaklaşımı ile desteklenmiş fen eğitiminin 6. Sını öğrencilerinin akademik başarısına ve fen dersine karşı tutumuna etkisi. Yüksek lisans tezi. Fırat Üniversitesi Eğitim Bilimleri Enstitüsü, Elazığ.

Aydın, S., Atalay, T. D. ve Göksu, V. (2017). Proje tabanlı öğrenme sürecinin ortaokul öğrencilerinin akademik öz-yeterlikleri ve motivasyonları üzerine etkisinin incelenmesi. Bartın Üniversitesi Ĕ̈itim Fakültesi Dergisi, 6(2), 676-688.

Bayraktar, H. V. (2015). Proje tabanlı öğrenme yaklaşımı. Uluslararası Sosyal Araştırmalar Dergisi, 8 (37), $709-718$.

Bozkurt Altan, E., Üçüncüoğlu, İ. ve Zileli, E. (2019). Yatılı bölge ortaokulu öğrencilerinin STEM alanlarına yönelik kariyer farkındalı̆̆ının araştırılması. Kastamonu Ĕ̈itim Dergisi, 27(2), 785-797.

Çakallığlu, S. N. (2008). Proje tabanlı öğrenme yaklaşımına dayal fen bilgisi öğretiminin akademik başarı ve tutuma etkisi, Yüksek lisans tezi, Çukurova Üniversitesi Sosyal Bilimleri Enstitüsü, Adana.

Çelikten, M., Şanal, M. ve Yeni, Y. (2005). Öğretmenlik mesleği ve özellikleri. Erciyes Üniversitesi Sosyal Bilimler Enstitüsü Dergisi, 1(19), 207-237.

Çetin, O. ve Şengezer, B. (2013). Ortaokul öğrencilerinin proje çalışmalarına ilişkin görüşleri. Ege Eğitim Dergisi, 14, 24-49.

Çıbık, S. A. (2006). Proje tabanlı öğrenme yaklaşımının fen bilgisi dersinde öğrencilerin mantıksal düşünme becerilerine ve tutumlarına etkisi. Yüksek lisans tezi. Çukurova Üniversitesi Sosyal Bilimleri Enstitüsü, Adana.

Civelekoğlu, M. Ş. ve Öztürk, Ş. (2010). İlköğretim fen ve teknoloji dersinde proje tabanlı öğrenme (PTÖ) yönteminin uygulanması ile ilgili öğretmen ve öğrenci görüşleri. İlköğretim Online, 9(3), 1189-1200.

Demirhan, C. (2002). Program geliştirmede proje tabanlı ögrenme yaklaşımı. Yüksek lisans tezi. Hacettepe Üniversitesi Sosyal Bilimleri Enstitüsü, Ankara.

Ekiz, D. (2003). Eğitimde araştırma yöntem ve metotlarına giriş, Ankara: Anı Yayıncılık.

Erdem, A. (2008). Proje tabanlı öğrenmenin ilköğretim yedinci sınıf öğrencilerinin bilgisayar dersi başarısına ve tutumuna etkisi. Yüksek lisans tezi. Sakarya Üniversitesi Sosyal Bilimleri Enstitüsü, Sakarya.

Erdem, M. (2002). Proje tabanlı öğrenme. Hacettepe Üniversitesi Eğitim Fakültesi Dergisi, 22, 172-179.

Filiz, A. Kocakülah, M. S. (2020). Fen eğitiminde proje tabanlı öğrenme yaklaşımı ile ilgili yapılan araştırmaların içerik analizi, Ihlara Eğitim Araştırmaları Dergisi, 5(2), 175-194.

Guskey, T. R., \& Sparks, D. (1996). Exploring the relationship between staff development and improvements in student learning. Journal of Staff Development, 17, 34-38.

İdin, Ş. ve Özdemir Şimşek, P. (2016). Proje tabanlı öğrenme kapsamında gerçekleştirilen ders dışı egzersiz çalışmalarına ilişkin öğrenci görüşleri. İlköğretim Online, 15 (3), 761-777.

İmer, N. (2008). İlköğretim fen ve teknoloji öğretiminde proje tabanlı öğrenme yaklaşımının öğrencilerin akademik başarı ve tutumuna etkisinin araştırılması. Yüksek lisans tezi. Gazi Üniversitesi Eğitim Bilimleri Enstitüsü, Ankara.

Karaçallı, S. (2011). Illköğretim 4. Sınıffen ve teknoloji dersinde proje tabanlı öğrenme yönteminin akademik başarıya, tutuma ve kalıcllı̆̆a etkisi. Yüksek lisans tezi. Mehmet Akif Ersoy Üniversitesi Sosyal Bilimleri Enstitüsü, Burdur.

Karaer, G., Karademir, E. ve Tezel, Ö. (2020). Proje tabanlı öğretimin fen laboratuvarı dersinde kullanımının sınıf öğretmeni adaylarının görüşlerine göre değerlendirilmesi. Eğitimde Nitel Araştırmalar Dergisi, 8(1), 73-95.

Karaer, F. ve Karaer, H. (2012a). Branş öğretmenlerine düzenlenen proje tabanlı hizmet içi eğitimlerin değerlendirilmesi (Samsun örneği). IV. Uluslararası Türkiye Eğitim Araştırmaları Kongresi. İstanbul, Türkiye.

Karaer, H. ve Karaer, F. (2012b). İlköğretim ve ortaöğretim öğretmenlerinin proje tabanlı hizmet içi eğitime katılma isteklerinin bazı değişkenler açısından incelenmesi. IV. Uluslararası Türkiye Eğitim Araştırmaları Kongresi, İstanbul, Türkiye.

Karaer, H., Karaer, F., Parmaksız, İ. ve Akaydın G. (2010). Ortaöğrenim öğretmenleri için düzenlenen bilim danışmanlığı ve eğitimi önünden destekleme çalıştayının etkililiğinin değerlendirilmesi. Uluslararası Öğretmen Yetiştirme Politikaları ve Sorunları Sempozyumu II. Ankara, Türkiye. 
Karaer, H., Karaer, F., Şahin, N. ve Parmaksız, İ. (2010). Ortaöğretim öğretmenlerine düzenlenen bilim danışmanlığı çalıştayının değerlendirilmesi. Milli Ĕ̆itim Dergisi, 39 (187), 225-239.

Karaer, H., Karaer, F. ve Şahin, N. (2009, 21-23 Mayıs). Sınıf öğretmenliğinde çevre eğitimi dersinin proje tabanlı öğrenme yaklaşımına göre uygulanması. 8. Ulusal sınıf öğretmenliği eğitimi sempozyumu Eskişehir, Türkiye.

Karaer, H. (2007). İlköğretim ikinci kademe 8. Sınıf öğrencilerinin fen bilgisi dersine yönelik tutumlarının bazı değişkenler açısından incelenmesi. Erzincan Üniversitesi Eğitim Fakültesi Dergisi, 9(1), 107-120.

Karasar, N. (2013). Bilimsel Araştırma Yöntemi (25. baskı). Ankara: Nobel Yayın Dağıtım.

Karasu, E. (2012). Illköğretim 6. ve 7. sınıf sosyal bilgiler derslerinde yapılan proje çalışmalarının öğretmen ve öğrenci görü̧slerine göre değerlendirilmesi (Kastamonu ili örneği). Yüksek lisans tezi. Kastamonu Üniversitesi Sosyal Bilimleri Enstitüsü, Kastamonu.

Keser, K. Ş. (2008). Proje tabanlı ögrenme yaklaşımının fen bilgisi dersinde başarı, tutum ve kalıcı öğrenmeye etkisi. Yüksek lisans tezi. Eskişehir Osmangazi Üniversitesi Fen Bilimleri Enstitüsü, Eskişehir.

Kılıç, İ. ve Özel, M. (2015). Proje tabanlı öğrenme yönteminin fen ve teknoloji derslerinde uygulamaları hakkında öğretmen ve veli görüşlerinin incelenmesi. Sakarya University Journal of Education, 5 (2), 7-20.

Kılıç, İ. ve Özmen, M. (2021). Hayat bilgisi dersinde proje tabanlı öğrenme yaklaşımının uygulanmasında öğretmen, öğrenci ve veli görüşlerinin incelenmesi. Trakya Üniversitesi Sosyal Bilimler Dergisi, 23(1), 449-470.

Kızkapan, O. (2015). İlköğretim 7. sını öğrencilerinin maddenin yapısı ve özellikleri ünitesindeki başarılarına ve fen bilimleri dersine karşı tutumlarına proje tabanlı ögrenmenin etkisi. Yüksek lisans tezi. Erciyes Üniversitesi Eğitim Bilimleri Enstitüsü, Kayseri.

Koparan, T., Karpuz, Y. ve Güven, B. (2014). Öğrencilerin proje tabanlı öğrenme yaklaşımı ile istatistik eğitimine yönelik görüşleri. Dicle Üniversitesi Ziya Gökalp Eğitim Fakültesi Dergisi, 22, 51-64.

Korkmaz, H. ve Kaptan, F. (2001). Fen eğitiminde proje tabanlı öğrenme yaklaşımı. Hacettepe Üniversitesi Eğitim Fakültesi Dergisi, 20, 193-200.

Köse, M. (2010). İlköğretim 7. sinuf fen ve teknoloji dersi “kuvvet ve hareket” ünitesinin ögrretiminde proje tabanl ögrrenme yaklaşımının öğrencilerin başarı ve tutumlarına etkisi. Yüksek lisans tezi. Selçuk Ün. Eğitim Bilimleri Enstitüsü, Konya.

Kummin, S., \& Rahman, S. (2010). The relationship between the use of metacognitive strategies and achievement in English. Procedia - Social and Behavioral Sciences, 7, 145-150.

Nacaroğlu, O., Arslan, M. ve Bektaş, O. (2019). Bilim ve sanat merkezi’nde yürütülen proje çalışmalarına ilişkin öğretmen görüşlerinin değerlendirilmesi. Asya Öğretim Dergisi, 7(2), 1-21.

Oktay, A. (1991). Öğretmenlik mesleği ve öğretmenin nitelikleri. Marmara Üniversitesi Atatürk Eğitim Fakültesi Eğitim Bilimleri Dergisi, 3(3), 187-193.

Olgun, H., Yavuz, A. ve Yokuş, E. (2019). Ortaöğretim proje hazırlama ders kitabı. (Baskı 1) Devlet kitapları, Ankara.

Özahioğlu, B. (2012). İlköğretim fen ve teknoloji dersinde proje tabanlı öğrenmenin bilimsel süreç becerilerine, başarı ve tutum üzerine etkisi. Yüksek lisans tezi. Çanakkale Onsekiz Mart Üniversitesi Eğitim Bilimleri Enstitüsü, Çanakkale.

Özel, M. (2013). Proje tabanlı ögrenme yönteminin ilköğretim 2. kademe fen ve teknoloji derslerindeki uygulanmasının incelenmesi. Yüksek lisans tezi. Trakya Üniversitesi Fen Bilimleri Enstitüsü, Edirne.

Quek, C. L., Wong, A. F. L., Diyaraharan, S., Liu, W. C. L., Peer, J., \& Williams, M. D. (2007). Secondary school students' perceptions of teacher-student interaction and students' attitudes towards project work. Learning Environments Research, $10,177-187$.

Sabuncuoğlu, O. (2016). Öğretmen gözlemlerinin öğrenmeyi öğrenmedeki yeri nedir: öğretmenin kariyerinde fark yaratabilir mi? Atatürk Üniversitesi Sosyal Bilimler Enstitüsü Dergisi, 20(1), 185-198.

Schneider, R. M., Krajcik, J., Marx, R. W., \& Soloway, E. (2002). Performance of students in project-based science classroom on a national measure of science achievement. Journal of Research in Science Teaching, 39(5), 410-422.

Sünbül, A. (1996). Öğretmen niteliği ve öğretimdeki rolleri. Kuram ve Uygulamada Eğitim Yönetimi, 8 (8), 597-608.

Türkmen, N. (2019). Proje tabanlı öğrenme yaklaşımının fen bilimleri dersinde öğrencilerin akademik başarl ve tutumuna etkisi. Yüksek lisans tezi. Trakya Üniversitesi Sosyal Bilimleri Enstitüsü, Edirne.

Yavuz, G. ve Yavuz, S. (2017). Fen eğitiminde proje tabanlı öğretimle ilgili tezlerin içerik analizi: Türkiye örneği (2002-2014). Mehmet Akif Ersoy Üniversitesi Ĕ̌itim Fakültesi Dergisi, 43, 255-282.

Yıldırım, A. ve Şimşek, H. (2006). Sosyal bilimlerde nitel araştırma yöntemleri. Ankara: Seçkin Yay. 


\section{Extended Abstract}

\section{Introduction}

In the process from the past to the present, the people have tried to solve the problems when they are faced with them. They can solve all or a little part of these problems with their efforts. They look for a new solution if they can't solve it. In this way, they find themselves in a development process by adding new information to the present information. These problems' solutions may not always happen a consciously and regular way. Whether it is conscious or accidental, the adventure of human beings to reach knowledge generally occurs as a result of an interaction. The way to reach information or to find solutions to problems can be happen in the case of processes such as curiosity, research, investigation, cognitive thinking, etc. At the same time, the rapid development of information and technology in our age requires people to work in cooperation.

Project-Based Learning which started earlier in developed countries within the education system, gained speed in our country after 2002 and become widespread especially after TUBITAK gave importance. In recent years, there are many studies being included in Project-Based Learning, being among the methods preferred in secondary and high schools, increasing the academic success level of the student, developing positive attitudes and behaviours towards science and science, encouraging students to become scientists, etc. in student-centred teaching. It is thought that this study, which shows the opinions of the students in the Regional Boarding Secondary School about the reasons for their request to prepare projects and take education, will contribute to the literature.

This research was carried out to analyse the opinions and thoughts of regional boarding secondary school students about request to prepare project and receive education. How do the opinions and thoughts of regional boarding secondary school students regarding the reasons for their desire to prepare project and receive education according to some variables change? The question was taken as the main problem of the research.

Four sub-problems have been identified within the scope of this main problem.

1- How the frequency and percentage do values of students' requests to prepare projects and receive education change?

2- How do the frequencies of the opinions and thoughts of the students regarding the reasons for their request to prepare project according to some variables change?

3- How do the frequencies of the opinions and thoughts of the students regarding the reasons for their request to receive education project according to some variables change?

4- How do the frequencies of the opinions and thoughts of the students regarding the benefits of project preparation and receive education according to some variables change?

\section{Method}

\section{Model of the Research}

This research is a study in the cross-sectional survey model. With this research, this model was deemed appropriate as it was tried to analyze the existing situation of students who requested to prepare projects, receive project education and do both together.

\section{Participants of the research}

Participants consisted of 123 students studying in their classes at the classes from $5^{\text {th }}$ grades to $8^{\text {th }}$ grades in a Boarding Regional Secondary School in the Black Sea Region in the autumn semester of the 2018-2019 academic years. The frequencies and percentages of the personal information of these students were given in tables. $45.5 \%$ of students are female and $54.5 \%$ are male. It is seen that the highest participation in the study was at $7^{\text {th }}$ grade $(33.3 \%)$, while at least $(18.7 \%)$ was in the $5^{\text {th }}$ grade. Only $4.9 \%$ of students stated that they didn't like science, $43.1 \%$ wanted to go to science high school, $30.9 \%$ wanted to work in security, $27.6 \%$ in education and $26.8 \%$ in health.

\section{Data collection tool}

It was collected from a two-part interview form and semi-structured face-to-face interviews. In the first part of the opinion form, there are five questions including the genders of the students, their classes, their liking of science, the type of high school they want to go to and their opinions on the professional group they want to work in the future. In the second part, there are five questions, including students' opinions about how to make projects. There 
are two closed and three open-ended questions in these five questions. After obtaining expert opinion before the opinion form was been copied, the form was finalized. In addition, semi-structured face-to-face interviews were conducted with volunteer students from each class and recorded with an audio recorder. In these interviews, a rich data set was created by confirming students' answers with questions similar to those on the opinion form.

\section{Data analysis}

The demographic characteristics of the students on the opinion form and the answers to two closed-ended questions were given in the form of frequency and percentage ratios, while descriptive analysis was used to analyze the answers to questions in open-ended and semi-structured interviews. The categories formed from the students' opinions are respectively "Request to prepare project", "Not request to prepare a project", "Request to receive project education", "Not request to receive project education" "Request to do both" and "Not request to do both" and codes in each category were given in the form of frequencies according to variables. In addition, the codes created in the category "Benefits of projects" were given in the form of frequencies.

\section{Findings}

According to the findings, it was determined that students' views on the reasons for their desire to prepare projects and receive education were similar. It was determined that $73.9 \%$ of the students wanted to prepare projects, $78.0 \%$ receive project education and $69.1 \%$ wants both to prepare the project and receive an education. It was determined that the opinions of the students regarding the reasons for the request to prepare and receive education were similar. On the other hand; that they are informed, loved, fun, exciting, and beautiful among the requests to prepare projects, and that the reasons why they do not want to prepare projects are difficult, narrowing, boring, and that the students who think they do not have the skills are more likely than other opinions. It has been determined that the opinions of the students 'request to receive education are similar. Students' opinions on the benefits of prepared project and receive education including "Learning new information", "Self-development", "Being successful in your courses and career", "Being fun, exciting, beautiful" and "Projects (stages, construction, etc.) to be able to know about " opinions were determined to be more than other opinions.

\section{Results and recommendations}

- It can be said that the vast majority of students want to prepare and study projects, and among the reasons they want to find solutions to the problems they face in daily life, they want to grow equipped even though they have hesitations and fears about the project,

- Students take more realistic approaches in their thoughts for the future as their class levels increase, many of them want to go to science high school, among the reasons they want to get a good education and reach the profession they dream of in the future,

Based on these results, it is proposed to make project-based learning to meet the students' request to prepare the project and receive education, to be in such a way as to satisfy their level of education, needs, and sense of curiosity and to give the necessary importance to provide opportunities. 